\title{
DISTRIBUTION OF ASIATIC BLACK BEAR AND ITS INTERACTION WITH HUMANS IN JIGME SINGYE WANGCHUCK NATIONAL PARK, BHUTAN
}

\author{
Letro Letro $^{1,2}$, Sangay Wangchuk ${ }^{3,4}$, Tashi Dhendup ${ }^{3,5}$ \\ ${ }^{1}$ Department of Forests and Park Services, Bhutan \\ ${ }^{2}$ University of Greifswald, Germany \\ e-mail:fr.lethro81@gmail.com \\ ${ }^{3}$ Ugyen Wangchuck Institute for Conservation and Environmental Research, Bhutan \\ ${ }^{4}$ Charles Sturt University, Australia \\ e-mail:swangchuk@uwice.gov.bt \\ ${ }^{5}$ University of Montana, USA \\ e-mail: tashid@uwice.gov.bt
}

Received: 18.07.2019. Revised: 09.12.2019. Accepted: 10.12.2019.

\begin{abstract}
We assessed the human-bear interactions and distribution patterns of the Asiatic black bear Ursus thibetanus in Jigme Singye Wangchuck National Park (JSWNP) in Bhutan through a questionnaire survey of park residents and by remote camera trapping. Our study revealed $26 \%(\mathrm{~N}=311)$ of the respondents experiencing one or another form of human-bear interaction. Crop damage accounted for the highest interaction rate at $65 \%$, followed by livestock depredation (25\%), between 2012 and 2016. About $10 \%$ of the interactions involved human mualing cases in 2006-2016. About $80 \%$ of the respondents expressed support for bear conservation influenced mainly by conservation awareness programmes. Observations from 39 camera trap stations across the national park indicated a wide distribution of Asiatic black bears in JSWNP, with a mean site use probability of 0.55 $(\mathrm{SE}=0.10, \mathrm{~N}=39)$. With emerging perceived threats such as habitat fragmentation and loss, retaliatory killing, and poaching, it is recommended that the national park management adopt conservation measures that will enable a harmonious coexistence between humans and bears. Habitat enrichment with natural food resources for the bear, equipping communities with conflict preventive measures, and advocating local people on bear conservation are some of the measures that need to be adopted in the national park.
\end{abstract}

Key words: Himalayan black bear, human-wildlife conflict, Protected Area, species conservation, Ursidae, Ursus thibetanus

\section{Introduction}

The Asiatic black bear, Ursus thibetanus G. Cuvier, 1823, is one of the five bear species found in Asia (Mills \& Servheen, 1994). The others include the Himalayan brown bear Ursus arctos Linnaeus, 1758, the Malayan sun bear Helarctos malayanus (Raffles, 1821), the sloth bear Melursus ursinus (Shaw, 1791), and the giant panda Ailuropoda melanoleuca (David, 1869). Ursus thibetanus is widely distributed from South-East Iran through Afghanistan and Pakistan, eastward along the lower foothills of the Himalayas in India, Nepal, Bhutan, China, Southern Russian Far East, and North and South Korea (Servheen et al., 1999). Islands in Asia with U. thibetanus include Japan (Hazumi, 1994), Taiwan, and possibly the Province of Hainan in China (Trent, 2010). Ursus thibetanus can be found in diverse forest habitats and altitudes ranging from sea level to more than $4500 \mathrm{~m}$ a.s.l. (Servheen et al., 1999). With the global population of U. thibetanus declining due to indiscriminate poaching for trade (Mills \& Servheen, 1994), retaliatory killing (Charoo et al., 2011), and habitat degradation and fragmentation (Liu et al., 2011), the species is included in CITES Appendix I (CITES, 2016) and listed as Vulnerable in the IUCN Red List of Threatened Species (Garshelis \& Steinmetz, 2016). However, there are only a few studies on $U$. thibetanus's ecology, population status and distribution, and the nature of human-bear interactions (Servheen et al., 1999; Sathyakumar, 2001; Garshelis \& Steinmetz, 2016).

Ursus thibetanus is found throughout Bhutan (Wangchuk et al., 2004), and the species is listed as a Schedule I species in the Forest and Nature Conservation Act of Bhutan (FNCA) 1995 (RGoB, 1995). Schedule I species, according to the FNCA, are the totally protected species in Bhutan. Such a high degree of protection is expected to counter the perceived threats of bear poaching for bile, habitat encroachment, and retaliatory killing.

On the other hand, conflicts have arisen between people and wildlife across Bhutan in recent times (Sangay \& Vernes, 2008) and U. thibetanus was reported as one of the conflicting predators (Wang et al., 2006a; Jamtsho \& Wangchuk, 2016). Interactions between $U$. thibetanus and humans span a diverse array of geographic and human demographic contexts as bears typically compete directly with humans for space, food, security, and cover (Charoo et al., 2011). 
Ursus thibetanus is known to damage agricultural and horticultural crops, apiaries, and fish farms, as well as injuring and killing livestock and humans (Hazumi, 1994; Chauhan, 2003; Ngoprasert et al., 2011; Fakhar-i-Abbas et al., 2015). There were reports of conflicts between $U$. thibetanus and humans in Jigme Singye Wangchuck in the past (Wang \& Macdonald, 2006) but the frequency and severity of conflicts are not known. Moreover, there is no information on the distribution pattern of bear within the national park for making informed conservation decisions either. In this paper, we report the distribution, habitat use, and nature of human-bear interactions in Jigme Singye Wangchuck National Park in central Bhutan.

\section{Material and Methods}

\section{Study Area}

Jigme Singye Wangchuck National Park (JSWNP) is the third largest national park in Bhutan (Fig. 1) with an area of $1730 \mathrm{~km}^{2}$ (JSWNP, 2014a). The national park is linked to Jigme Dorji National Park and Wangchuck Centennial National Park (WCNP) to the north, Phrumsengla National Park to the west, and Phibsoo Wildlife Sanctuary to the south by biological corridors. Biological corridors are areas set aside to connect protected areas for enabling safe movement of wildlife. There are eight biological corridors in Bhutan, which were first established in 1999 (NCD, 2004). JSWNP also shares a boundary with Royal Manas National Park to the south. With the altitude ranging from $464 \mathrm{~m}$ a.s.1. to $4925 \mathrm{~m}$ a.s.1., JSWNP has diverse vegetation types with representation from the sub-tropical forest to alpine scrubs. Thirty nine species of mammals including threatened species such as Bengal tiger Panthera tigris tigris (Linnaeus, 1758), Leopard Panthera pardus (Linnaeus, 1758), Red panda Ailurus fulgens (F. Cuvier, 1825), Golden langur Trachypithecus geei (Khajuria, 1956), Serrow Capricornis thar (Hodgson, 1831), Musk deer Moschus chrysogaster (Hodgson, 1839), and Gaur Bos gaurus (C. H. Smith, 1827) are found here. The national park is classified into two management zones: a core zone for strict conservation without human interventions, and a multiple-use zone where sustainable harvesting of resources is allowed (JSWNP, 2014b). Close to 5000 people reside in 561 households in the multipleuse zone of the national park, maintaining a close interaction between nature and people.

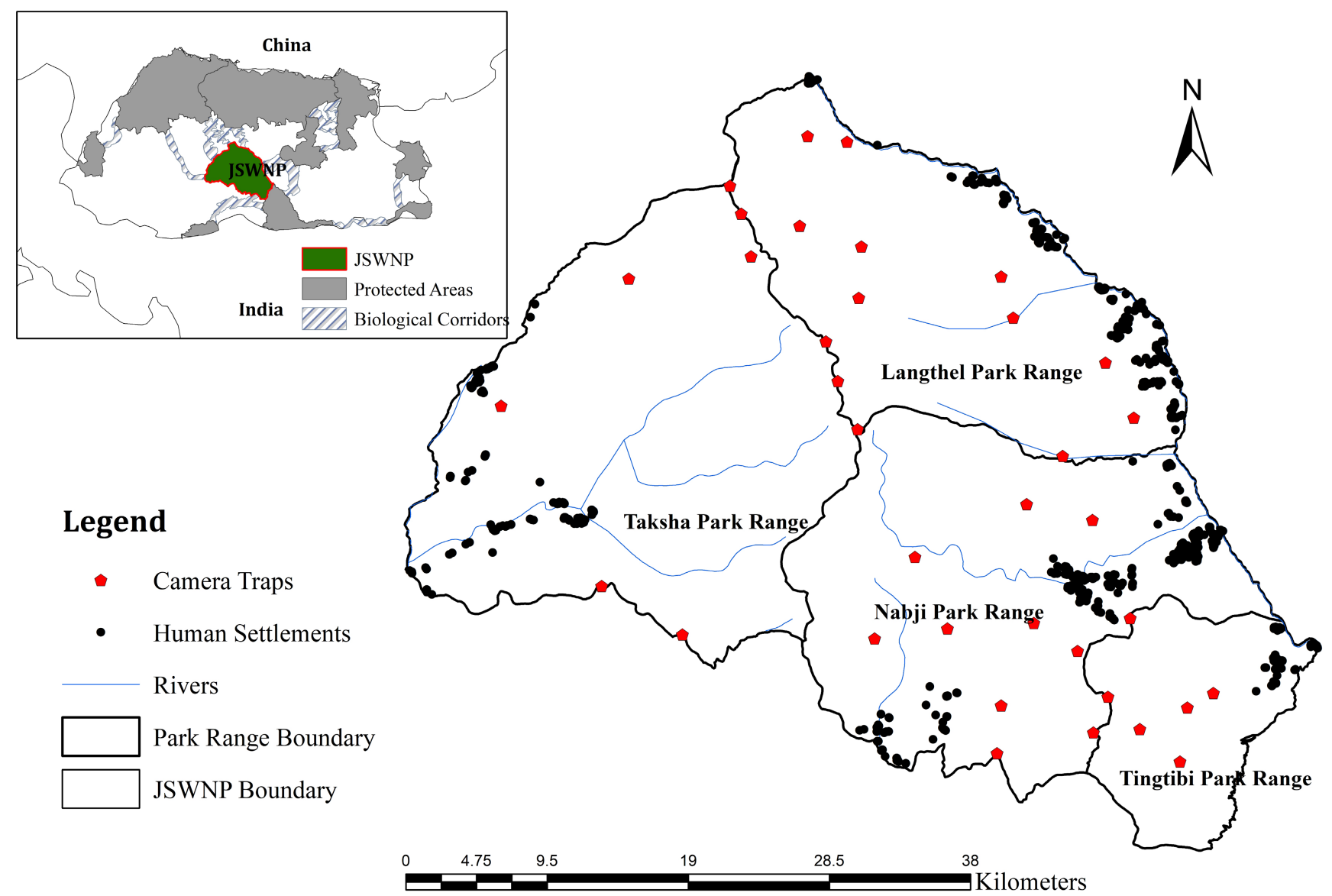

Fig. 1. Map showing the location of camera traps and human settlements in which questionnaire survey was conducted in Jigme Singye Wangchuck National Park. The location of the study area, Jigme Singye Wangchuck National Park in central Bhutan and Bhutan's location in the region is also shown (on the small map). 


\section{Field Survey}

Questionnaire survey

We conducted a questionnaire survey to understand human-bear interactions and perception of people towards bear conservation. Efforts were made to interview as many households (HHs) as possible. However, we were able to interview only $311 \mathrm{HHs}$, representing $53 \%$ of the total national park residents, who were present at their homes during our door to door survey. The number of respondents varied among different Park Ranges owing to the difference in number of households: Taksha Park Range (72), Nabji Park Range (135), Langthel Park Range (57), and Tingtibi Park Range (47). Park Ranges are smaller administrative jurisdictions within the national park for the ease of managing the national park. We categorised human-bear interactions as (1) crop damage, (2) livestock depredation, or (3) attacks on humans. Information on the former two were sought from the interviewees based on the incidents that occurred in the three years preceding the survey, i.e., 2014 until April 2016, so that respondents can recollect the incidents that occurred to their household. However, in case of attacks on humans, we tried to get information from 2006 to 2016 as the number of such incidents was very low.

\section{Remote camera trapping}

We used camera traps to generate data for estimating site use probability of $U$. thibetanus in the Jigme Singye Wangchuck National Park. We laid grids of $2.5 \times 2.5 \mathrm{~km}$ throughout the national park, the area of which is slightly bigger than the average home range $\left(3.55 \mathrm{~km}^{2}\right)$ of bears in general as reported by studies in India (Sunar et al., 2012) where habitats are similar to JSWNP. Camera traps were set up in 39 random grids representing the different habitat types and altitude gradient of the entire national park between July - December 2016. At each station, we installed a Reconyx ${ }^{\mathrm{TM}}$ camera trap, $45 \mathrm{~cm}$ above the ground and recorded coordinates and altitude for each using Garmin GPS. We placed the camera traps along trails and ridges, near waterholes and salt licks, and in areas with a high density of animals to maximise the probability of detecting wild animals including $U$. thibetanus. We kept a minimum distance of at least two km between each station, to increase the probability of detecting more individuals than repeatedly detecting the same individual. The camera traps were deployed for at least 60 days to increase detection probability.

\section{Data Analysis}

Human-bear interactions and people's perceptions

We used descriptive analysis through frequency distribution and multivariate logistic regression to analyse the pattern of human-bear interactions. Preliminary bivariate tests (cross-tabulations and analyses of variance) were carried out and a significance level of $p \leq 0.05$ was used to select the variables to be included in the multivariable model for determining their influence in predicting the response variable. Logistic regression analyses were made using the backward elimination of variables to generate a parsimonious final model. Gender, age, education level, knowledge about bears, human-bear conflict incidents, knowledge of forest rules, and whether they attended an awareness education programme or not were used as predictor variables that influenced peoples' perceptions. The results were reported as estimated coefficients $(\beta)$, standard error of the coefficient (SE), Wald statistics $\chi^{2}$ values, and level of statistical significance (p). The associations were considered significant at $\mathrm{p} \leq 0.05$. Statistical software R studio (R Core Team, 2018) with relevant packages such as «dplyr» (Wickham et al., 2018), «car» (Fox \& Weisberg, 2011), and «lmtest» (Zeileis \& Hothorn, 2002) were used for performing the regression analysis.

\section{Distribution and habitat use probability}

We ran single-season single-species occupancy models developed by MacKenzie et al., (2002) in the programme PRESENCE (Hines, 2006) to understand distribution and habitat use probability of bears in JSWNP. The photographic records of $U$. thibetanus were sorted from each camera trap using the programme ReNamer (Sanderson \& Harris, 2013) and its extension tool Occupancy Matrix was used to generate detection histories. The 75day camera trap effort was collapsed into sampling periods of various durations such as 10 days per occasion (8 occasions), 12 days (6 occasions), and 15 days (5 occasions), each occasion representing a repeat observation. The occasion with the optimum sampling period was selected based on the chi-square goodness-of-fit test for the multivariate global model (MacKenzie \& Bailey, 2004) and 15 days proved optimal (c hat $=1.01, p=0.40$ ). Occupancy models can accommodate covariates that influence detection and occupancy probabilities and is modelled as a function of a survey and site-specific covariates (MacKenzie et al., 2006). Based on existing literature on $U$. thibetanus (Sathyakumar, 
2001; Charoo et al., 2011; Jamtsho \& Wangchuk, 2016), we took into account six site covariates, viz., altitude (m), slope $\left(^{\circ}\right)$, forest types, land cover $(\%)$, distance to river (m), distance to settlement (m), and two survey covariates viz., survey effort (number of days the camera was actively running) and survey area (National Park zones, $\mathrm{CZ}=$ core zone, $\mathrm{MZ}=$ Multiple-use zone) for model development. All site covariates for JSWNP were derived from the national data of Bhutan, which were processed using QGIS 2.14 (QGIS Development Team, 2018) and ArcGIS 10.3. Forest type data were obtained from land use and the land cover map of Bhutan 2017 (FRMD, 2017), while the forest cover data came from a 30-m resolution global forest change (GFC) cover for the year 2017 (Hansen et al., 2013). The distance to major rivers and human settlements was generated using the Euclidean distance tool in ArcGIS, the vector layers of which were rasterised to generate the distances in metres. All continuous site covariates were Z-standardised to zero mean and one standard deviation (Sunarto et al., 2012). A two-step process to estimate the probability of detection (p) and the site use probability $(\psi)$ was followed for building logical model combinations (MacKenzie et al., 2005). Collinearity was checked for all the covariates and no two highly correlated covariates were used together during the modelling. We assessed model support based on Akaike information criterion (AIC) values (Burnham \& Anderson, 2004) and all plausible multivariate models within $\triangle \mathrm{AIC}<2$ were considered to be equally supported by data. The model fit was examined by a goodness-of-fit test with 10000 bootstrapping. The mean untransformed beta coefficient $(\beta)$ estimate from the best multivariate model was used to predict the site occupancy of the species. It was also used to measure the degree and direction of the covariate effect on the site-use probability.

\section{Results \\ Respondent Demography}

The respondents' ages ranged between 16 to 84 years with the average age of 47.87 years
$(\mathrm{SE}= \pm 1.25)$, with approximately $67 \%$ being male. About $69 \%$ of the respondents had not attended any formal education while the rest attended either non-formal education or some form of formal education. However, about $71 \%$ of the respondents attended conservation awareness programmes conducted by the national park officials and about $85 \%$ of the respondents were aware of the provisions of forestry act and rules such as the illegality of killing wildlife and others relevant to their livelihoods.

\section{Human-bear interactions and people's per- ception of bear conservation}

The majority (about $86 \%$ ) of respondents were aware of the presence of $U$. thibetanus in their locality with about $74 \%$ of them having direct sighting and the rest reported to have come across bear sign. Most of the bear sightings and sign were reported in the forests near the settlements (within 3 $\mathrm{km}$ ), which is designated as multiple-use zone by the national park, however about 4\% sighted bears in the agricultural fields.

Human-bear interactions are prevalent in the national park with $26 \%$ of the respondents reporting some form of interactions with bears, which included depredation of crops $(65 \%)$, livestock depredation (25\%), and attack on humans $(10 \%)$ (Table 1$)$.

About $80 \%$ of the respondents expressed their support for conservation of bears and other species citing reasons such as ecological value, cultural beliefs, and the risk of extinction, and bears as a part of national wealth (Fig. 2). The results from the multivariate regression analysis indicated that people's support for conservation was significantly explained by three variables: awareness education, personal knowledge of basic forest rules, and age of the respondent $\left(\chi^{2}(3,310)=169.60, \mathrm{p}<0.05\right)($ Table 2$)$. On the perception of threats to bears, about $59 \%$ of the respondents felt there will be threats of habitat fragmentation due to infrastructure development, possible retaliation by people, and rampant poaching.

Table 1. Number of human-bear interactions in Jigme Singye Wangchuck National Park (2012-2016 except for human mauling (2006-2016))

\begin{tabular}{|l|c|c|c|c|}
\hline \multirow{2}{*}{ Interaction Types } & \multicolumn{4}{|c|}{ Number of respondents with Human-bear interaction cases in each Park Ranges } \\
\cline { 2 - 5 } & Taksha $(\mathrm{N}=72)$ & Nabji $(\mathrm{N}=135)$ & Langthel $(\mathrm{N}=57)$ & Tingtibi $(\mathrm{N}=47)$ \\
\hline Crop damage & $8(11.11 \%)$ & $19(14.07 \%)$ & $10(17.54 \%)$ & $15(31.91 \%)$ \\
\hline Livestock depredation & $3(4.17 \%)$ & $3(2.22 \%)$ & $14(24.56 \%)$ & $0(0 \%)$ \\
\hline Human mauling & $3(4.17 \%)$ & $1(0.74 \%)$ & $4(7.01 \%)$ & $0(0 \%)$ \\
\hline
\end{tabular}


Table 2. Results of the multivariate logistic regression analyses on the respondents' perception on conservation needs for Ursus thibetanus in Jigme Singye Wangchuck National Park in 2016

\begin{tabular}{|l|c|c|c|c|c|}
\hline \multicolumn{1}{|c|}{ Variables } & Coefficient $(\beta)$ & SE & Wald $\chi^{2}$ & $\mathrm{z}$ value & $\mathrm{p}$ value \\
\hline (Intercept) & 0.65 & 1.13 & - & 0.57 & 0.566 \\
\hline Awareness education programme attended (Binary) & 2.91 & 0.64 & 20.44 & 4.52 & $<0.001$ \\
\hline Age of respondents (Continuous) & -0.06 & 0.02 & 9.56 & -3.09 & $<0.001$ \\
\hline Aware of basic forest rules (Binary) & 1.71 & 0.92 & 3.39 & 1.84 & 0.065 \\
\hline
\end{tabular}

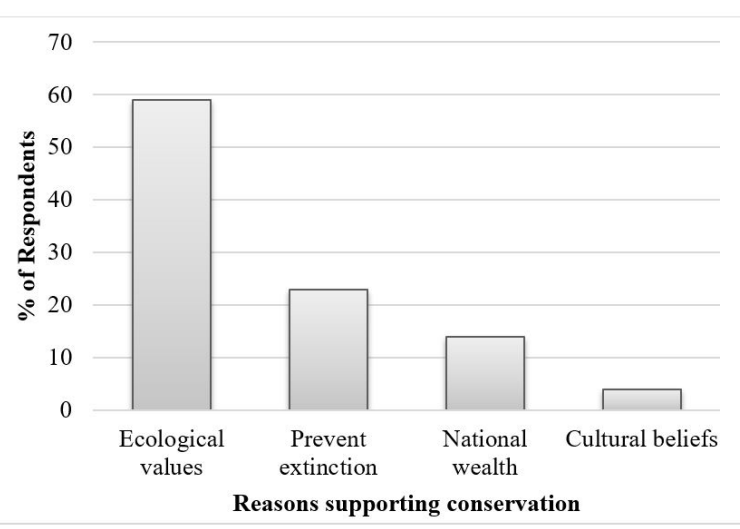

Fig. 2. Proportion of respondents supporting conservation of Ursus thibetanus after each respondent choosing one option in Jigme Singye Wangchuck National Park in $2016(\mathrm{~N}=249)$.

\section{Distribution and habitat use probability}

Ursus thibetanus was detected at 20 camera trap locations out of the total 39 , producing a naïve occupancy of 0.51 . A total of 678 images of bear were obtained from 64 independent events. We detected bears between $1218 \mathrm{~m}$ a.s.1. and $4389 \mathrm{~m}$ a.s.1. Out of the 20 locations where we detected bears, 11 were inside the core zone, and nine were in the multiple-use zone.
A univariate occupancy model showed the distance to a settlement, altitude, and the distance to a river as most supported covariates on the bear site use probability $(\psi)$, followed by forest cover, land use types, and slope (Table 3). Four multivariate models were found to be strongly supported by our data (models within $\triangle \mathrm{AIC}<2$ ) and the model with altitude and distance to river had the highest support (Table 4), yielding a mean predicted proportion of the site use probability of $0.55(\mathrm{SE}=0.10)$ :

probit $\left(\psi_{i}\right)=\beta 0+\beta_{E L E}$ altitude $_{i}+\beta_{R I V}$ distance to river ${ }_{i}$,

where $\beta 0$ refers to intercept, $\beta_{i}$ are the coefficient estimates of the covariates, « ${ }_{i}$ » is the site surveyed. The site use probability was relatively higher in the Multiple use zone $(0.58(\mathrm{SE}=0.10))$ as compared to the Core Zone (0.53 ( $\mathrm{SE}=0.09)$ ) (Fig. 3). The estimates of untransformed beta coefficients indicate the altitude had a negative association $(-0.962, \mathrm{SE}=0.50)$ on the bear site use probability and the distance to a river was having a positive association $(1.046, \mathrm{SE}=0.58)$. Models supported by data suggests the distance to a settlement having a negative influence $(-0.396, \mathrm{SE}=$ 0.66 ) on bears' habitat use probability as well.

Table 3. Univariate site use probability models for six site covariates and the null model for Ursus thibetanus in Jigme Singye Wangchuck National Park in 2016

\begin{tabular}{|l|c|c|c|c|c|c|}
\hline Model & AIC & $\Delta$ AIC & AIC wt & Model Likelihood & K & -2 Log Likelihood \\
\hline$\Psi$ (SET), p (.) & 222.29 & 0 & 0.32 & 1 & 2 & 218.29 \\
\hline$\Psi$ (ALT), p (.) & 222.84 & 0.55 & 0.24 & 0.75 & 2 & 218.84 \\
\hline$\Psi$ (RIV), p (.) & 223.22 & 0.93 & 0.20 & 0.63 & 2 & 219.22 \\
\hline$\Psi$ (GFC), p (.) & 224.22 & 1.93 & 0.12 & 0.38 & 2 & 220.22 \\
\hline$\Psi$ (LU), p (.) & 226.10 & 3.81 & 0.05 & 0.15 & 2 & 222.10 \\
\hline$\Psi$ (SLO), p (.) & 226.68 & 4.39 & 0.04 & 0.11 & 2 & 222.68 \\
\hline$\Psi(),. \mathrm{p}()$. & 227.26 & 4.97 & 0.03 & 0.08 & 2 & 223.26 \\
\hline
\end{tabular}

Note: Covariates used are ALT = Altitude, $\mathrm{SLO}=$ Slope, $\mathrm{LU}=$ Land use types, GFC = Forest Cover, SET = Distance to settlement, and RIV = Distance to river; $\mathrm{AIC}=$ Akaike Information Criterion corrected for small sample size; $\triangle \mathrm{AIC}=$ Relative difference between AIC of subsequent models compared to the top model; AIC Wt $=$ AIC weight; $\mathrm{K}$, number of parameters, Detection probability was kept constant $\mathrm{p}($.).

Table 4. Multivariate model selection results for Ursus thibetanus site use probability in Jigme Singye Wangchuck National Park in 2016

\begin{tabular}{|l|c|c|c|c|c|c|}
\hline Model & AIC & $\Delta$ AIC & AIC wt & Model Likelihood & K & -2 Log Likelihood \\
\hline$\psi($ ALT + RIV), p (.) & 220.22 & 0 & 0.40 & 1 & 3 & 214.22 \\
\hline$\Psi$ (SET + RIV), p (.) & 221.05 & 0.83 & 0.27 & 0.66 & 3 & 215.05 \\
\hline$\psi($ ALT + SET + RIV), p (.) & 221.86 & 1.64 & 0.18 & 0.44 & 4 & 213.86 \\
\hline$\Psi$ (ALT + SLO + RIV), p (.) & 222.17 & 1.95 & 0.15 & 0.38 & 4 & 214.17 \\
\hline
\end{tabular}

Note: Covariates used are ALT $=$ Altitude, $\mathrm{SLO}=$ Slope, $\mathrm{SET}=$ Distance to settlement, and RIV $=$ Distance to river; AIC $=$ Akaike Information Criterion corrected for small sample size; $\triangle \mathrm{AIC}=$ Relative difference between AIC of subsequent models compared to the top model; AIC Wt = AIC weight; K, number of parameters, Detection probability was kept constant $\mathrm{p}($.$) .$ 


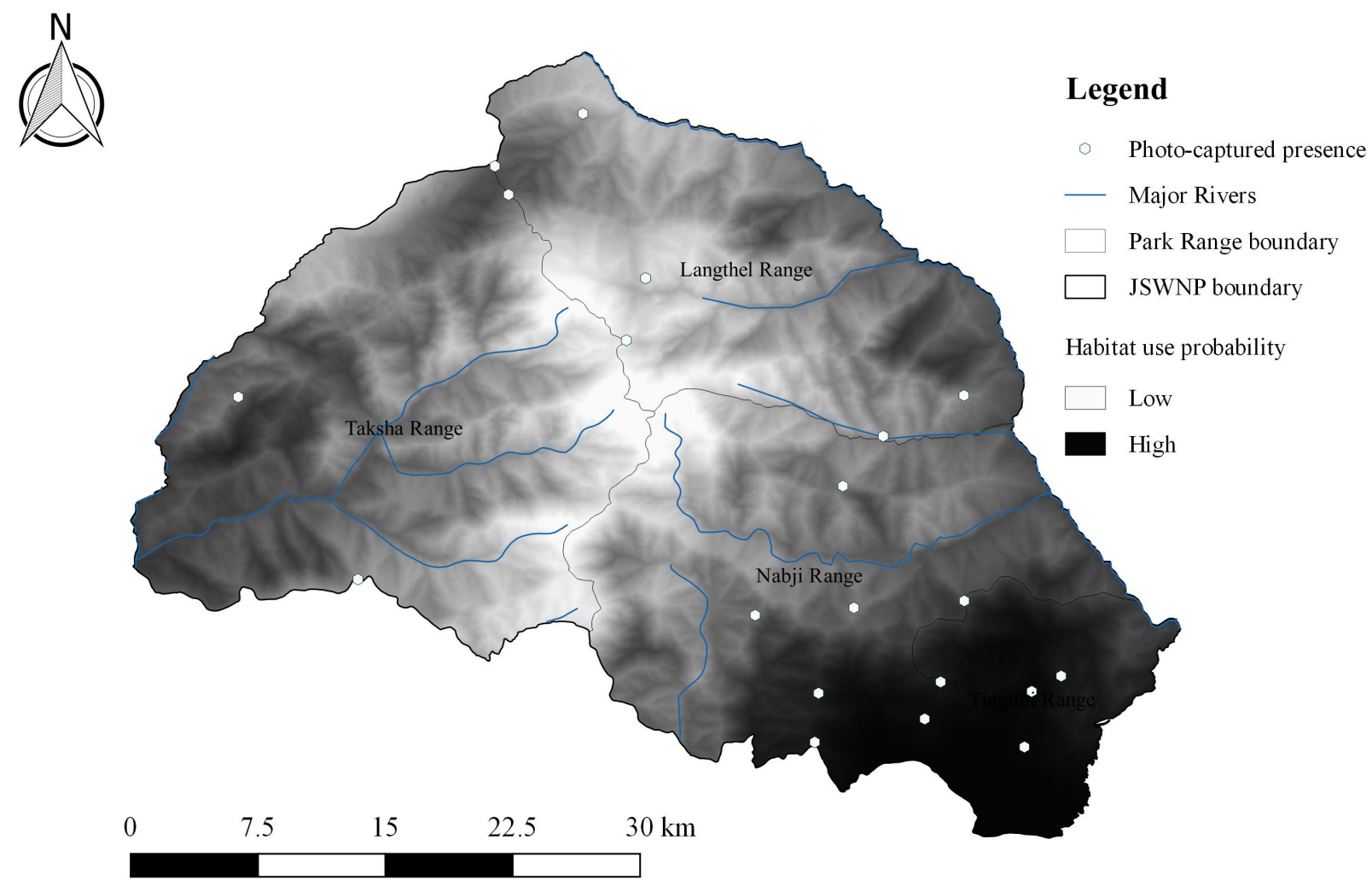

Fig. 3. Estimated proportion of area used by Ursus thibetanus in Jigme Singye Wangchuck National Park in 2016 as ascertained from occupancy modelling framework.

For the detection model, neither the survey area (Core zone and Multiple-use zone) nor camera trap effort had a significant influence on detection probability $(p)$. Therefore, in the multivariate combinations, covariates influencing detection probability (p) was kept as null $\psi($ covariate), $p($.$) .$

\section{Discussion}

The $U$. thibetanus is a common species in JSWNP with the species being recorded from the sub-tropical forests to the alpine zone clearly indicating that this species is a habitat generalist (Escobar et al., 2015; Garshelis \& Steinmetz, 2016). However only four camera stations above $4000 \mathrm{~m}$ a.s.l. captured a bear, with the highest altitude being at $4389 \mathrm{~m}$ a.s.1. We had 11 camera stations out of 39 above $4000 \mathrm{~m}$ a.s.l. The occupancy modelling also indicated a negative association between altitude and site use probability with the proportion of area used by bears at lower altitude being bigger than that of higher altitude. Sathyakumar (2001) also reported that bears generally do not move above $4500 \mathrm{~m}$ a.s.l. because of less food availability in the alpine scrub vegetation.

In JSWNP, $U$. thibetanus was reported as a conflicting species in earlier studies (Wang \& Macdonald, 2006; Wang et al., 2006a). However, bears accounted for just $8 \%$ of the total livestock kills (Wang
\& Macdonald, 2006) and 7\% of the total crop damage (Wang et al., 2006a) in 2000. With only $26 \%$ of the respondents reporting some form of interactions with a bear, our study results align with the findings of Wang \& Macdonald (2006) and Wang et al. (2006a). Thus, we can possibly conclude that the intensity of conflict caused by bears in JSWNP is not as serious as perceived by the communities.

Amongst the reported interactions, crop damage was found to be most common followed by livestock depredation and mauling of humans, similar to findings from Jamtsho \& Wangchuk (2016) in WCNP and by Charoo et al. (2011) from Dachigam National Park, Kashmir, India. Incidents of crop damage can be attributed to the availability food crops like maize in the communities, which is reported to be a preferred food by bears (Fakhar-i-Abbas et al., 2015; Ali et al., 2017). Bears are opportunistic omnivores and consume more plant than animal matter (Joshi et al., 1997). Yet, $U r$ sus thibetanus often depredate livestocks in the cattle sheds and during winters in the region (Chauhan, 2003; Yadav et al., 2009; Charoo et al., 2011). However, livestock depredation in JSWNP is not as high as that of crop damage incidents. Though no investigation was done, the loss of livestock to bears in JSWNP can be largely related to husbandry practices such as free grazing in the forests as this is the most common meth- 
od of herding practice in JSWNP. Sethy \& Chauhan (2011) from India and Jamtsho \& Wangchuk (2016) from WCNP also reported similar causes leading to livestock attacks by bears.

Most of the human-bear conflict areas were found to be either in the multiple-use zone or within a three-kilometre buffer from settlements, which was consistent with the results from our occupancy modelling. Our modelling results suggest that bears commonly use areas in the multiple-use zone which was corroborated by $86 \%$ of the respondents reporting the presence of bears in the forests near the villages. Similar observations were also reported from India by Sathyakumar (2001) and Charoo et al. (2011) wherein they reported bears preferring to stay near the human settlements, possibly attracted to croplands and domesticated food resources. In the WCNP in Bhutan, Jamtsho \& Wangchuk (2016) reported that people sighted more bears during the season of crop production. It is established that fragmented habitats with adjacent human habitations and croplands or orchards increase the close interactions between human and bears (Bargali et al., 2005). However, unlike in India where human settlements expand towards forest fringes (Charoo et al., 2011), people in Bhutan complain of expanding forests bringing wildlife next to their door (Wang et al., 2006b). A preliminary report on land cover change analysis in JSWNP from 1995 to 2015 also showed an increase in forest cover by 4\% (Letro, 2016).

That over $80 \%$ of the respondents expressed support for conservation of the bear may be an indication of people's willingness to live alongside bears at the current nature and intensity of conflicts, this may also be credited to the rigorous conservation awareness programmes initiated by the national park management. Liu et al. (2011) reported that education programmes can help increase local people's tolerance towards wildlife. We make this statement as a conservation awareness programme for the communities in an annual event in JSWNP and no cases of poaching were recorded by the national park management in the last 10 years. However, we caution that the nature of the bears' habitat choice and encroaching forest in the settlements might heighten human-bear conflicts in the future, questioning the survival of bears and safety of people's livelihoods. We put this on record as over $50 \%$ of the respondents expressed perceived threats that may emerge in the future.

\section{Conclusions}

While the conservation situation of $U$. thibetanus looks promising in JSWNP with reference to humanbear interaction, conservation threats cannot be denied with various developmental works happening within the vicinity of the national park. Human-bear conflicts may intensify in the future due to human encroachment into the bear's habitat or vice versa (Sangay \& Vernes, 2008), resulting in communities losing their tolerance to wildlife, which might incite retaliation. Therefore, it is vital that effective crop protection measures such as electric fencing are put in place, and livestock guarding and herd management alternatives are explored to reduce a loss to people. Habitat fragmentation and loss due to development is impacting every species in the biosphere (Escobar et al., 2015) and such anthropogenic disturbances will not spare habitat generalist species such as $U$. thibetanus. Conversely, expanding forests in JSWNP reinforces the need for a detailed assessment of the feeding habits of bears, as the lack of adequate food resources in the wilderness drives bear closer to settlements where palatable food resources are easily available, which could lead to human-bear conflict incidences. Subsequently, habitat enrichment with natural food resources where required, equipping communities with conflict preventive measures, and advocating local people on bear conservation should be carried out. Furthermore, to ensure human-bear coexistence and to achieve conservation success, the national park management should work towards preventing the three perceived threats: habitat fragmentation, possible retaliation, and poaching. With JSWNP forming an indispensable conservation landscape in central Bhutan and providing a linkage to other protected areas through biological corridors, the conservation success in JSWNP will have greater implications for bear conservation in Bhutan.

\section{References}

Ali A., Zhou Z., Waseem M., Khan M.F., Ali I., Asad M., Qashqaei A.T. 2017. An assessment of food habits and altitudinal distribution of the Asiatic black bear ( $U r$ sus thibetanus) in the Western Himalayas, Pakistan. Journal of Natural History 51(11-12): 689-701. DOI: 10.1080/00222933.2017.1303097

Bargali H.S., Akhtar N., Chauhan N.P.S. 2005. Characteristics of sloth bear attacks and human casualties in North Bilaspur Forest Division, Chhattisgarh, India. Ursus 16(2): 263-267. DOI: 10.2192/1537-6176(2005)016[0263:CO SBAA]2.0.CO;2

Burnham K.P., Anderson D.R. 2004. Multimodel inference: Understanding AIC and BIC in model selection. Sociological Methods and Research 33(2): 261-304. DOI: 10.1177/0049124104268644

Charoo S.A., Sharma L.K., Sathyakumar S. 2011. Asiatic black bear-human interactions around Dachigam National Park, Kashmir, India. Ursus 22(2): 106-113. DOI: $10.2307 / 41304062$ 
Chauhan N.P.S. 2003. Human casualties and Human casualties and livestock depredation by black and brown bears in the Indian Himalaya, 1989-98. Ursus 14(1): 84-87.

CITES. 2016. Convention on International Trade in Endangered Species of Wild Fauna and Flora: The CITES Appendices. Retrieved: 10 January 2017 from UN Environment Programme. Geneva, Switzerland. Available from: http://www.cites.org

Escobar L.E., Awan M.N., Qiao H. 2015. Anthropogenic disturbance and habitat loss for the red-listed Asiatic black bear (Ursus thibetanus): Using ecological niche modeling and nighttime light satellite imagery. Biological Conservation 191: 400-407. DOI: 10.1016/j.biocon.2015.06.040

Fakhar-i-Abbas, Bhatti Z.I., Haider J., Mian A. 2015. Bears in Pakistan: Distribution, Population Biology and $\mathrm{Hu}-$ man Conflicts. Journal of Bioresource Management 2(2): 1-13.

Fox J., Weisberg S. 2011. An $\{R\}$ Companion to Applied Regression. Available from: http://socserv.socsci.mcmaster.ca/jfox/Books/Companion

FRMD. 2017. Land Use and Land Cover of Bhutan 2016, Maps and Statistics. Thimphu: Forests Resources Management Division. 28 p.

Garshelis D., Steinmetz R. 2016. Ursus thibetanus (errata version published in 2017). In: The IUCN Red List of Threatened Species 2016: e.T22824A114252336. Available from: http://dx.doi.org/10.2305/IUCN.UK.2016-3. RLTS.T22824A45034242.en

Hansen M.C., Potapov P.V., Moore R., Hancher M., Turubanova S.A., Tyukavina A., Thau D., Stehman S.V., Goetz S.J., Loveland T.R., Kommareddy A., Egorov A., Chini L., Justice C.O., Townshend J.R.G. 2013. HighResolution Global Maps of 21 ${ }^{\text {st }}$ Century Forest Cover Change. Science 342(6160): 850-853. DOI: 10.1126/ science. 1244693

Hazumi T. 1994. Status of Japanese black bear. International Conference on Bear Research and Management 9(1): 145-148.

Hines J.E. 2006. PRESENCE - Software to estimate patch occupancy and related parameters. Available from: https:// www.mbr-pwrc.usgs.gov/software/presence.html

Jamtsho Y., Wangchuk S. 2016. Assessing patterns of human-Asiatic black bear interaction in and around Wangchuck Centennial National Park, Bhutan. Global Ecology and Conservation 8: 183-189. DOI: 10.1016/j. gecco.2016.09.004

Joshi A.R., Garshelis D.L., Smith J.L.D. 1997. Seasonal and Habitat-Related Diets of Sloth Bears in Nepal. Journal of Mammalogy 78(2): 584-597. DOI: 10.2307/1382910

JSWNP. 2014a. Conservation management plan, Jigme Singye Wangchuck National Park. Trongsa: JSWNP. 23 p.

JSWNP. 2014b. Zoning for Jigme Singye Wangchuck National Park. Trongsa: JSWNP. 7 p.

Letro L. 2016. Land Cover Change in Jigme Singye Wangchuck National Park, Bhutan: 1995-2010 and beyond. Trongsa: JSWNP. 12 p.

Liu F., McShea W.J., Garshelis D.L., Zhu X., Wang D., Shao L. 2011. Human-wildlife conflicts influence attitudes but not necessarily behaviors: Factors driving the poaching of bears in China. Biological Conservation 144(1): 538-547. DOI: 10.1016/j.biocon.2010.10.009

MacKenzie D.I., Bailey L.L. 2004. Assessing the fit of siteoccupancy models. Journal of Agricultural, Biological, and Environmental Statistics 9(3): 300-318. DOI: 10.1198/108571104X3361

MacKenzie D.I., Nichols J.D., Lachman G.B., Droege S., Andrew J., Langtimm C.A. 2002. Estimating Site Occupancy Rates When Detection Probabilities Are Less Than One. Ecology 83(8): 2248-2255. DOI: 10.1890/0012-9658(2002)083[2248:ESORWD]2.0.CO;2

MacKenzie D.I., Nichols J.D., Sutton N., Kawanishi K., Bailey L.L. 2005. Improving inferences in population studies of rare species that are detected imperfectly. Ecology 86(5): 1101-1113. DOI: 10.1890/04-1060

MacKenzie D.I., Nichols J.D., Royle J.A., Pollock K.H., Bailey L.L., Hines J.E. 2006. Occupancy Estimation and Modeling: Inferring Patterns and Dynamics of Species Occurrence. Burlington, USA: Academic Press, Burlington. 324 p.

Mills J., Servheen C. 1994. The Asian Trade in Bears and Bear Parts : Impacts and Conservation Recommendations. Bears: Their Biology and Management 9(1994): 161-167.

NCD. 2004. Bhutan Biological Conservation Complex: A Landscape Conservation Plan - Way Forward. In: Secretary. Thimphu: Department of Forests and Park Services.

Ngoprasert D., Steinmetz R., Reed D.H., Savini T., Gale G.A. 2011. Influence of fruit on habitat selection of Asian bears in a tropical forest. Journal of Wildlife Management 75(3): 588-595. DOI: 10.1002/jwmg.83

QGIS Development Team. 2018. QGIS Geographic Information System. Open Source Geospatial Foundation Project. Available from: https://www.qgis.org

R Core Team. 2018. R: A Language and Environment for Statistical Computing. Available from: https:// www.r-project.org/

RGoB. 1995. Forests and Nature Conservation Act of Bhutan. Thimphu: Royal Government of Bhutan.

Sanderson J.J.G., Harris G. 2013. Automatic data organization, storage, and analysis of camera trap pictures. Journal of Indonesian Natural History 1(1): 11. DOI: 10.1890/0012-9623-91.3.352

Sangay T., Vernes K. 2008. Human-wildlife conflict in the Kingdom of Bhutan: Patterns of livestock predation by large mammalian carnivores. Biological Conservation 141(5): 1272-1282. DOI: 10.1016/j.biocon.2008.02.027

Sathyakumar S. 2001. Status and management of Asiatic black bear and Himalayan brown bear in India. Ursus 12: 21-30. DOI: 10.2307/3873225

Servheen C., Herrero S., Peyton B., Pelletier K., Moll K., Moll J. 1999. Asiatic Black Bear Conservation Action Plan. In: C. Servheen, S. Herrero, B. Peyton, K. Pelletier, K. Moll, J. Moll (Eds.): Bears: status survey and conservation action plan. Gland: IUCN. P. 199-218.

Sethy J., Chauhan N. 2011. Use and Trade of Bear Body Parts: Impact and Conservation in Arunachal Pradesh State of India. International Journal of Bio-Resource and Stress Management 2(4): 409-415. 
Sunar D., Chakraborty R., Sharma B.K., Ghose P.S., Bhutia P.T., Pradhan S. 2012. Status and Distribution of Asiatic Black Bear and the status of humanbear conflict in Senchal Wildlife Sanctury Darjeeling, West Bengal. New Delhi: WWF-India and West Bengal Forest Department, Wildlife Division I. DOI: $10.13140 / 2.1 .1622 .3526$

Sunarto S., Kelly M.J., Parakkasi K., Klenzendorf S., Septayuda E., Kurniawan H. 2012. Tigers need cover: Multiscale occupancy study of the big cat in Sumatran forest and plantation landscapes. PLOS ONE 7(1): e30859. DOI: 10.1371/journal.pone.0030859

Trent J.A. 2010. Ecology, Habitat Use and conservation of Asiatic black bears in the min mountains of Sichuan provence, China. MSc. Thesis. Blacksburg: Virginia Polytechnic Institute and State University. 102 p.

Wang S.W., Macdonald D.W. 2006. Livestock predation by carnivores in Jigme Singye Wangchuck National Park, Bhutan. Biological Conservation 129(4): 558-565. DOI: 10.1016/j.biocon.2005.11.024

Wang S.W., Curtis P.D., Lassoie J.P. 2006a. Farmer Perceptions of Crop Damage by Wildlife in Jig- me Singye Wangchuck National Park, Bhutan. Wildlife Society Bulletin 34(2): 359-365. DOI: 10.2193/0091-7648(2006)34[359:FPOCDB]2.0.CO;2

Wang S.W., Lassoie J.P., Curtis P.D. 2006b. Farmer attitudes towards conservation in Jigme Singye Wangchuck National Park, Bhutan. Environmental Conservation 33(2): 148-156. DOI: 10.1017/ S0376892906002931

Wangchuk T., Thinley P., Tshering K., Yonten D., Pema B. 2004. A Field Guide to the Mammals of Bhutan (1 ${ }^{\text {st }}$ edition). Royal Goverment of Bhutan. $182 \mathrm{p}$.

Wickham H., François R., Henry L., Müller K. 2018. dplyr: A Grammar of Data Manipulation. Available from: https://cran.r-project.org/package $=$ dplyr

Yadav B.P., Sathyakumar S, Bhatta S.R. 2009. Assessment of Asiatic black bear (Ursus thibetanus) Human conflicts at Dhorpatan Hunting Reserve, Nepal. A report submitted to the International Association for Bear Research and Management, USA. 51 p.

Zeileis A., Hothorn T. 2002. Diagnostic Checking in Regression Relationships. $R$ News 2(3): 7-10. Available from https://cran.r-project.org/doc/Rnews/

\title{
РАСПРОСТРАНЕНИЕ ГИМАЛАЙСКОГО МЕДВЕДЯ И ЕГО ВЗАИМОДЕЙСТВИЕ С ЛЮДЬМИ В НАЦИОНАЛЬНОМ ПАРКЕ «ДЖИГМЕ-СИНГАЙ-ВАНГЧУК» (БУТАН)
}

\author{
Л. Летро ${ }^{1,2}$, С. Вангчук $\kappa^{3,4}$, Т. Дендап ${ }^{3,5}$ \\ 'Департамент лесопарковой службы, Бутан \\ ${ }^{2}$ Грайфсвальдский университет, Германия \\ e-mail:fr.lethro81@gmail.com \\ ${ }^{3}$ Институт охраны окружающей среды и экологических исследований им. У. Вангчука, Бутан \\ ${ }^{4}$ Университет Чарльза Стёрта, Австралия \\ e-mail:swangchuk@uwice.gov.bt \\ ${ }^{5}$ Университет Монтань, США \\ e-mail:tashid@uwice.gov.bt
}

В данной работе нами оценены особенности распространения гималайского медведя (Ursus thibetanus), а также взаимодействия между ним и человеком в национальном парке «Джигме-Сингай-Вангчук» (НПДСВ) в Бутане. Были использованы опросные сведения жителей национального парка и данные, полученные с помощью фотоловушек. Наше исследование выявило, что $26 \%$ ( $=311)$ респондентов испытывают по меньшей меру одну из форм взаимодействия человека и медведя. В период 2012-2016 гг., наносимый урожаю ущерб составил самый высокий уровень взаимодействия на уровне $65 \%$, меньшую долю составило хищничество медведем скота (25\%). Около $10 \%$ взаимодействий было связано с травмированием человека в период 2006-2016 гг. Около 80\% респондентов выразили поддержку сохранению Ursus thibetanus, что было вызвано, главным образом, программами по повышению осведомленности населения. Данные, полученные с использованием 39 фотоловушек на всей территории НПДСВ, показали широкое распространение особей в национальном парке со средней вероятностью использования участка $0.55(\mathrm{SE}=0.10, \mathrm{~N}=39)$. В связи с возникающими предполагаемыми угрозами, такими как фрагментация и утрата мест обитания, ответные убийства и браконьерство, рекомендуется, чтобы руководство национального парка приняло меры по сохранению вида, которые обеспечат гармоничное сосуществование человека и медведей. Увеличение природных пищевых ресурсов гималайского медведя на территории исследования, оснащение местных поселений человека мерами по предотвращению конфликтов с медведем и защита местного населения в вопросах сохранения медведей являются некоторыми из мер, которые необходимо принять в национальном парке «Джигме-Сингай-Вангчук».

Ключевые слова: Ursidae, Ursus thibetanus, гималайский черный медведь, конфликт между человеком и дикой природой, ООПТ, сохранение видов 